\title{
COMPARISON OF SERUM HEPATITIS B VIRUS REPLICATION MARKERS IN PATIENTS WITH CHRONIC HEPATITIS B: STUDIES ON HBeAg/ANTI-HBe SYSTEM, VIRAL DNA POLYMERASE AND HBV-DNA
}

\author{
Joa Renato Rebello PINIO (1), Luis Edmundo Pinto da FONSECA (2), Yu SONG (1), Yteriko MIYAMOTO (1), \\ Flair Jose CARRILIro (2), Celso Francisco Hernandes GRANATO (3) \& Luiz Cactano da SILVA (2)
}

\begin{abstract}
SUMMARY
The detection of HBV.DNA in serum by molecular hybridization is the most sensitive and specific marker of replication and infectivity of hepatitis $B$ virus and curcently is proposed as a routine dragnostic technique in the follow up of $\mathrm{HBV}$ - related diseases. Comparing different techniques already described. we found that direct spotting of serum samples on nitrocellulose membranes under vacuum filtration, followed by denaturing and neutralizing washes is more practical, simple. sensible and reproducible.

DNA polymerase assay using phosphonoformic acid as specific viral inhibitor has shown $86.8^{\circ}$; of concordance with HBV DNA detection, and so, it is an useful alternative in the follow up of hepatitis B chroric patients.

We found $19.2 \%$ HBeAg positive samples with no other markers of viral replica. tion and no anti-HBe positive sample had detectable HBV DNA. Discordance bet ween the 2 systems have been extensively described, and we confirm this for the first time in our country. Molecular biological techniques are essential to determine the replication status of chronic hepatitis B patients.
\end{abstract}

KEY WoRDS: Hepatitis B: Molecular hybridization: DNA polymerase: HBV-DNA: HBV replication markers: Chronic hepatitis $B$.

\section{INTRODUCTION}

Hepatitis B is a worldwide public health pro blem involving more than 200 million people as Hepatitis B Virus (HBV) carriers, with high risk of developing severe chronic liver disease, cirrho sis and hepatocellular carcinoma ${ }^{27}$. Its aetiolo gical agent has been extensively studied and characterized and is now classified in the new group of Hepadnaviridae, which includes other animal partial double - strand DNA hepatotropes virus that share many other common features with the human virus ${ }^{14}$.

During the natural history of this disease, there is a initial period with active viral replication, corresponding to the acute phase. In most of the cases, the evolution is benign, and the

(1) Molecular Blology Branch. Division of Virology. Instituto Adolfo Lutz, Sao Paulo, SP. Brazil.

(2) Clinical Hepatology Branch (LIM 07), Department of Gastroenterology and Hepatology Laboratory (LIM 47). Instituto de Medicina Tropical. Faculdade de Medieina da Universidade de Sao Paulo. Sao Paulo, SP. Brazil.

(3) Hepatitis Blanch, Division of Virology, Instituto Adolfo Lutz. Saio Paulo, SP. Brazil.

Address for correspondence: Dr. Luiz Caetano da Silva. Instituto de Medicina Tropical. Faculdade de Medieina da Universidade de: Sao Paulo. Av. Dr. Eneas de Carvalho Aguiar, 470. CEP 05403 Sao Paulo. SP. Brazil 
PINHO. J. R. R.: FONSECA. L. E. P. da. SONG. YU: MIYAMOTO. Y.; CARRILHO. F J : GRANATO. C F. H \& SILVA, L. C. da - Comparison of serum hepatitis $B$ virus replication markers in patients with chronic hepatitis B: studies on HBeAg Anti HBe system viral DNA polymerase and HBV-DNA. Rev. Inst. Med. trop. S. Paulo. 31(5): $328 \cdot 335.1989$

disease is aborted at this stage. In some cases, however. the host immune system is not capable to neutralize viral replication, and the disease progresses with continued viral replication for more than 6 months, characterizing the chronic forms of hepatitis B. In other cases, the viral DNA becomes integrated in the host cellular genome, and the viral replication ceases or decrea ses to undetectable levels ${ }^{32}$.

The assessment of $\mathrm{HBV}$ replication status in following these patients is very important for prognosis, infectivity monitoring. and, further more, for indication and follow up of antiviral or corticosteroid therapy $\mathrm{y}^{6}$.

Many serum markers have been developed to characterize viral replication. Initially. it was shown that the detection of HBeAg in sera was related in many cases with other evidences of viral replication ${ }^{23}$. HBeAg, detected by standard immunoassays, is a soluble antigen, and its syn thesis occurs in the liver generally when the virus is actively replicating ${ }^{13}$. However, some direct methods to detect Dane particles constituents have shown discordance between the presence of viral replication and the detection of $\mathrm{HBeAg}^{\mathrm{B}}$.

KAPLAN et al., $1973^{16}$ developed a technique to detect the HBV DNA polymerase activity in serum after ultracentrifugation. This technique is very cumbersome and not suitable for routine screening. LIN et al, $1984^{19}$ avoided the ultracentrifugation step using phosphonoformic acid as a specific viral polymerase inhibitor, creating a simpler and more sensitive method suitable for routine screening.

Detection of HBV DNA in serum by mole. cular hybridization was developed by some groups in the early 80 's $\mathrm{s}^{1.3 .}{ }^{18,30}$ and is currently proposed as a routine diagnostic assay in the follow up of HBV related diseases. The superio rity of this technique has led to the detection of a more sensitive and specific marker of replication and infectivity of $\mathrm{HBV}^{9}$. The use of this tech nique allowed the detection of $\mathrm{HBV}$ homologous sequences in HBsAg negative chronic hepatitis cases $^{4 .}{ }^{10}$. Since then discrepances between the HBeAg/anti-HBe system and direct HBV-INA detection have been described.
Hybridization techriques described so far vary in many crucial features: direct inmobi lization of samples on to nitrocellulose membra nes ${ }^{18}$, pre-treatment of samples with proteinase $\mathrm{K}^{22}$, previous denaturation of samples with So dium hydroxide ${ }^{26}$, utilization of Dextran Sulphate in washes ${ }^{21}$. WALTER et al, $1986^{24}$ compared various techniques and proposed pre treatment of samples with formalin-sarkosyl as the most sensitive one, with no other treatment. Other groups have also shown that proteases digestion has adverse effects in sensitivity ${ }^{i 1}$

Comparisons of the " $e$ " system with others parameters of viral replication has led to varia ble results. Some groups found $67 \% 22$ and $68 \%$; HBeAg positive cases also HBV DNA positive For other groups, about 90 to $100 \% \mathrm{HBeAg}$ posi tive cases have detectable $\mathrm{DNA}^{2.18 .26 .30}$. Consi dering anti-HBe cases, less concordance is found, with very high geographic variability ${ }^{17}$ : in Northern Europe and USA anti.HBe positive patients were rarely HBV-DNA positive ${ }^{15.28}$, but in Italy $^{2}$, Greece ${ }^{18}$ and Taiwan ${ }^{7}$ more than half anti HBe positive patients have detectable serum viral genornes.

Considering the data discussed above, the aims of our study are: first, compare the hybridi zation technique proposed by WALTER et al. with Scotto's technique proposed by ZELDIS et al. and the technique utilized by us: second, compare the DNA polymerase assay developed by LIN et al. with the detection of HBV. DNA: and, finally, compare the detection of $\mathrm{HBeAg}$. anti HBe, viral DNA polymerase and HBV -DNA in 38 serum samples from chronic hepatitis $B$ patients

\section{MATERIAL ANO METHODS}

REAGENTS - Restriction endonucleases for isolating HBV.DNA from the vector DNA were supplied by Pharmacia and Sigma. Radioactive probes were labeled to specitic activities be tween $10^{i}$ and $10^{\circ} \mathrm{cpm}$ ug with DNase I and DNA polymerase I from Sigma using alpha -.. ${ }^{32} \mathrm{P}$-dATP manufactured at Instituto de Quinica da USP ra gentle gift of Dr. J.C.C. Maia and Dr. M.H. Juliani) $(800 \mathrm{mCi}$ mol). Nitrocellulose membranes BA85 were supplied from Schleicher \& Schuell. Samples were concentrated using a 
PINHO. J. R R : FONSECA. L. F. P da: SONG. YU: MIYAMOTO. Y: CARRILHO. F. J.: GRANATO. C. F. H. \& SIL.VA, L. C da - Comparison of serum hepatitis B virus replication markers in patients with chronic hepatitis 13: studies on HBeAg Anti HBe system, viral DNA polymerase and HBV-DNA. Rev. Inst. Med. trop. S. Paulo, 31(5): 328335.1989 .

manifold apparatus manufactured at Tecnica Permatron «Sāo Paulo. SP . Hybridizations were performed in heat sealed plastic bags. Autora diographies were performed with Kodak QH S likm and intensifying screens. ${ }^{3} \mathrm{H}$ - dTTP was stupplied from Amersham. Other reagents were mainly supplied by Sigma or Merck.

PREPARATION OF HBV-DNA PROBES - Cloned HBV-DNA was prepared in Escheri chia coli HB101 transformed by p211 (a gentle gift of Dr. Francis Galibert, Laboratoire D'He matologie Experimentale, Centre Hayem. Hopi tal St. Louis, Paris, Francel according to MA NIA TIS et al, $1982^{20}$. This plasmid contains the entire HBV genome cloned in the EcoRI site of pBR322. Probes were labelled by nick transla tion as described by RIGBY et al. 11976$)^{-2.4}$. Stan dards were prepared by serial dilutions of puri fied HBV DNA in water in a way that each 25 $\boldsymbol{\mu l}$ of solution contains always $100 \mu \mathrm{g}$ of sheared herring sperm DNA and HBV DNA quantities cited in the text. Serum samples standard were made by diluting a strong positive sample with a negative sample to the concentrations cited in the figures.

\section{PREPARATION OF SAMPLES FOR HYBRIDIZATION:}

TECHNIQUE A - Routine laboratory tech nique is a modified Liebermann's technique. Samples ( $25 \boldsymbol{\mu l}$ ) were directly applied onto a nitrocellulose membrane (previously soaked in water) using a manifold system. The filters where then submitted to a denaturing treatment with $\mathrm{NaOH} 0.5 \mathrm{M}, \mathrm{NaCl} 1 \mathrm{M}$ for 20 minutes, neutralized with Tris $\mathrm{HCl} 0.1 \mathrm{M} \mathrm{pH} 7.4, \mathrm{NaCl} 0.5 \mathrm{M}$ for 5 minutes twice and then rinsed with $2 \times$ SSC 5 minutes twice.

TECHNIQUE B - A modified Scotto's technique. Samples $(25 \mu \mathrm{l})$ were incubated previously with $25 \mu \mathrm{l} 2 \mathrm{M} \mathrm{NaCl}$ and $50 \mu \mathrm{l} 1 \mathrm{M} \mathrm{NaOH}$ for 10 minutes in microtitration plaques wells and then filtered through a nitrocellulose membrane (previously soaked in $6 \mathrm{x}$ SSC) using a manifold system. Filters were then neutralized as descri bed above.
TECHNIQUE C - Walter's technique samples $25 \mu$ ) were denatured in $10 \times$ SSC. 2 $\mathrm{N} \mathrm{NaOH}, 15 \%$ formaldehyde and $0.5 \%$, Sarkosyl at $70^{\prime} \mathrm{C}$ for 10 minutes and then filtered through a nitrocellulose membrane using the manifold system. Filters were then neutralized as descri bed above.

Whatever was the technique used. filters were air dried and then baked for 2 hours at $80 \mathrm{C}$ in vacuum oven. Procedures were performed at room temperature, unless other temperature is cited

\section{PRE -HYBRIDIZATION AND HYBRIDIZATION}

PRE.HYBRIDIZATION was performed submerging the filter in $20 \mathrm{ml}$ of $5 \mathrm{x}$ SSC, $1 \mathrm{x}$ Denhardt, $0.1 \mathrm{M}$ Sodium Phosphate $\mathrm{pH} 7.5,1$ mM EDTA, $0.1 \mathrm{mg} \mathrm{ml}$ freshly heat denatured sheared herring sperm DNA at $65^{\circ} \mathrm{C}$ for at least 2 hours.

HYBRIDIZATION was performed with 10 $\mathrm{ml}$ of $4 \times \mathrm{SSC}, 2.5 \mathrm{x}$ Denhardt, $0.1 \mathrm{M}$ Sodium phosphate pH 7.5.1 mM EDTA, $0.2 \mathrm{mg} / \mathrm{ml}$ freshly denatured sheared herring sperm DN $A_{2}$, freshly heat denatured nick translated probe $110^{\circ} \quad 10$ cpm ml gentle shaking at $65^{\circ} \mathrm{C}$ overnight.

REMOVAL OF NON-SPECIFIC HYBRIDI ZATION was made by filter treatment twice in $2 \times$ SSC, $0.1 \%$ SDS, $65^{\circ} \mathrm{C}, 10$ minutes each, $1 \times$ SSC, $0.1 \%$ SDS, $65 \mathrm{C}, 10$ minutes, and $0.1 \times \mathrm{SSC}$ $0.1 \%$ SDS, $65^{\circ} \mathrm{C}, 10$ minutes.

AUTORADIOGRAPHY - Filters were air dried and exposed for 2 and 7 days to film and intensifying screens cited above.

DETERMINATION OF VIRAL POLYME RASE ACTIVITY - Lin's technique modified - in two $1.5 \mathrm{ml}$ plastic tubes each serum sample (25 $\mu$ l) is incubated at $37^{\circ} \mathrm{C}$ for 16 hours in $1 \mathrm{M}$ Tris pH 7.4: $\mathrm{KCl} 0.15 \mathrm{M}$; $\mathrm{MgCl} 245 \mathrm{mM}$ : $\mathrm{NH}_{4} \mathrm{Cl}$ $55 \mathrm{mM} ; 2$ - mercaptoetanol $0.15 \%$ : Nonidet P-40 $0.8 \%, 20 \mathrm{nM}$ each non-radiolabelled nucleotide and $1 \mu \mathrm{Ci} 3 \mathrm{H}$-dTTP. In one of the 2 tubes was added $10 \mathrm{mM}$ phosphonoformic acid as specific viral polymerase inhibitor. The reaction was 
PINIIO. J. R. R.; FONSECA, L. E. P. da: SONG. Yu: MIYAMOTO. Y.; CARRILHO, F. J.; GRANATO, C. F. I1. \& SILVA, L. C. da - Comparison of serum hepatitis B virus replication markers in patients with chronic hepatitis B: studies on HBeAg Anti HBe system, viral DNA polymerase and HBV-DNA. Rev. Inst. Med. trop. S. Paulo, $31(5): 328335,1989$

then stopped adding Pronase $1 \mathrm{mg} / \mathrm{ml}$, that breaks viral capsid. Samples were then deposed on $2.5 \mathrm{~cm}$ diameter $\mathrm{GF} / \mathrm{C}$ filters and non incorporated nucleotides were removed by three washings in $5 \%$ tricloroacetic acid, $50 \mathrm{mM}$ Sodium Pirophosphate. After drying, filters were counted in scintillation solution in a beta-counter. Samples were considered positive when there is a significant difference between the 2 tubes, compared to negative controls.

DETECTION OF HBeAg AND ANTI HBe was performed with Abbott diagnostic Kits.

SAMPLES - 38 HBsAg positive serum samples from chronic hepatitis $B$ patients were assayed by the 3 methods described above.

\section{RESULTS}

Comparative results between the three sam ples preparation procedures are shown in figure 1. In terms of detection of purified cloned HBV DNA, all the techniques could detect as little as $100 \mathrm{pg}$ of DNA diluted as described above. No hybridization signal was detected with the negative control sera. When comparing the detection of our standard serum sample dilutions, techniques $\mathrm{A}$ and $\mathrm{B}$ gave signals till the 1/16 dilution, but technique $\mathrm{C}$ shown no signal, even with the half-diluted sample.

Operationally the most simple technique is by far technique A that needs no separated treat-

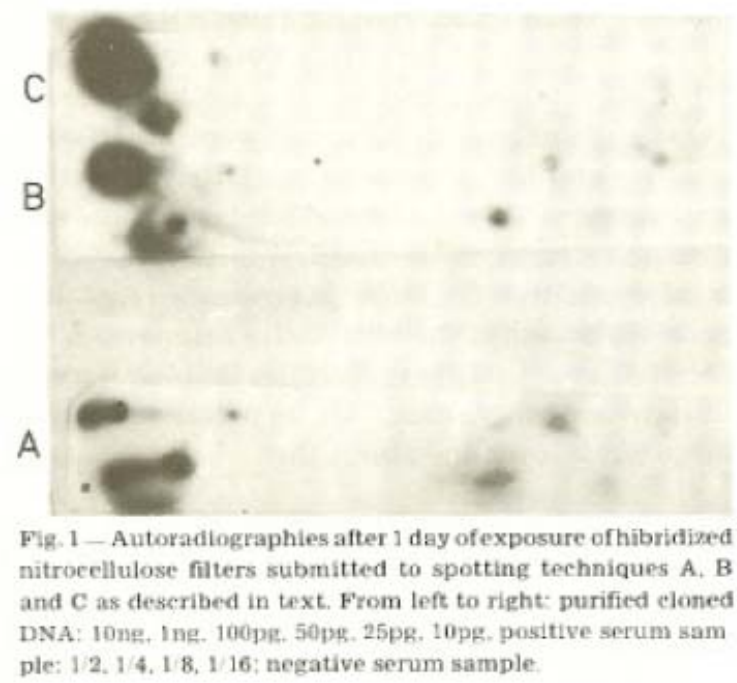

ment of individual serum samples and allows a rapid and efficient filtration of samples. Tech nique $B$, besides a longer operation time, elicits in some samples the appearance of protein clots that block total filtration of samples in commer cial manifold systems. Considering these results, the other hybridizations were performed accor ding to technique $\mathrm{A}$. Longer autoradiographic exposures 17 days) allow the detection of as little as $10 \mathrm{pg}$ of purified DNA, as shown in figure 2 , without compromising specificity

The results of the analysis of 38 serum samples by the four serologic methods described above, are shown in table 1 . Hibridization signals with varied intensity over a clear background from some of these samples were shown in figure 3 even with some spillage and no round spot caused by the manifold apparatus available.

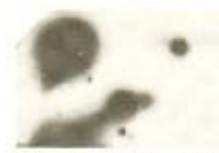

Fig. 2 - Autoradiography of hybridized nitrocellulose filter after 7 days of exposition performed according to technique A Serdal dilutions of HBV DNA as deseribed in text. From ieft to right $10 \mathrm{ng}$, $1 \mathrm{ng}, 100 \mathrm{pg}, 50 \mathrm{pg}, 25 \mathrm{pg}, 10 \mathrm{pg}, 1 \mathrm{pg}$. Positive serum sample dilutions $1 / 2,1 / 4,1 / 8,1 / 16$; negative serum sam ple.

TABLE 1

\begin{tabular}{|c|c|c|c|c|c|c|}
\hline & & $\begin{array}{c}\text { DNA } \\
\text { and } \\
\text { Pol. } \\
+ \\
\end{array}$ & $\begin{array}{c}\text { DNA } \\
+ \\
\text { Pol. } \\
- \\
\end{array}$ & $\begin{array}{c}\text { DNA } \\
-- \\
\text { Pol. } \\
+ \\
\end{array}$ & $\begin{array}{l}\text { DNA } \\
\text { and } \\
\text { Pol }\end{array}$ & Total \\
\hline I & $\begin{array}{l}\text { HBeAg + } \\
\text { Anti HBe }\end{array}$ & $\begin{array}{c}17 \\
65.5 \%\end{array}$ & $\begin{array}{c}3 \\
11.5 \%\end{array}$ & $\begin{array}{c}1 \\
3.9 \%\end{array}$ & $\begin{array}{c}5 \\
19.7 \%\end{array}$ & 26 \\
\hline & $\begin{array}{l}\text { HBeAg + } \\
\text { Anti HBe }+\end{array}$ & 0 & 0 & 0 & 1 & 1 \\
\hline & $\begin{array}{l}\mathrm{HBeAg-} \\
\text { Anti } \mathrm{HBC}+\end{array}$ & 0 & 0 & $\begin{array}{c}1 \\
11.1 \%\end{array}$ & $\begin{array}{c}8 \\
88.9 \% \\
\end{array}$ & 9 \\
\hline & $\begin{array}{l}\text { HBeAg - } \\
\text { Anti HBe - }\end{array}$ & 0 & 0 & 0 & 2 & 2 \\
\hline \multicolumn{2}{|c|}{ Total } & 17 & 3 & 2 & 16 & 38 \\
\hline
\end{tabular}

Comparative results of hybridization (DNA) and DNA polyme rase POL 1 assays in 4 different groups aecording to $\mathrm{HB}$. Ag an ti HBe status.

\section{DISCUSSION}

Development of molecular biology allowed the standardization of very specific and sensitive 
PINHO, I. R. R. FONSECA, L. E. P. da: SONG. Yu: MIYAMOTO, Y: CARRILHO. F. J.: GRANATO. C. F. H. \& SILVA. L. C da - Comparison of serum hepatitis $B$ virus replication markers in patients with chronic hepatitis B: studies on HBeAg/Anti-HBe system, viral DNA polymerase and HBV-DNA. Rev. Inst. Med. trop. S. Paulo. 31(5): 328335,1989

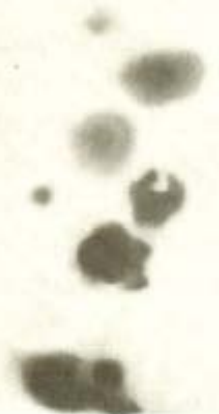

Fig. 3 - Autoradiography of a nitrocellulose filter containing spotted serum samples and hybridized as deseribed in the text. The filter contains negative samples and positive samples of varying intensity spotted in alternate wells. Results were ex pressed from + to ++++ according to the signal intensity

methods driven to the direct detection of com. plete HBV particles components, such as DNA polymerase and viral DNA. Initially restrained to research laboratories, these techniques have been so simplified that. nowadays, the detection of HBV DNA and DNA polymerase are consi dered essential diagnostic tools for determining the replication status of chronic hepatitis $B$ pa tients, necessary for indication, follow-up and prognosis of antiviral or corticosteroids thera py ${ }^{6}$.

Since its first application in the beginning of this decade. many groups proposed several cliferent procedures for serm HBV IDNA deter tion. Recently, WAITER et al. 1987 and Z.ELDIS et al., $1986^{31}$ compared some different techniques, and each proposed one different technique as the best one. We compared the Scotto's technique proposed by ZEIJDIS et al. and Walter's tecnique with our rotine technique which is a modification of Liebermann's techni. que. We got disappointing results with Walter's technique, and, comparable results using Scot to's procedures.

In our hands, previous denaturation of se rum samples could elicit appearance of protein clots that will block filtration in commercial ma nifold apparatus. Other group using this techni que utilise a self planned equipment with larger wells. that will not be blocked by these $\operatorname{clots}^{206}$. Most of the groups proposing direct spotting of serum samples do not perform vacuum filtration to concentrate them, as the porus diameter of nitrocellulose membranes $(220$ or $450 \mathrm{~nm}$ ! is lar ger than the diameter of Dane particle (42 $\mathrm{nm}$ ). and some virus are not retained on nitrocellu Iose. WAI,TER et al., $1987^{23}$ have even slinwed positive hybridization signals in four overloaded membranes submitted to vacuum filtration. Ho wever, these groups had to work with smaller quantities of serum $(5 \mu)$ than us $(25 \mu l)$, because samples diffuse rapidly through nitrocellulose 15 $\boldsymbol{\mu l}$ sample directly spotted corresponds to about $1 \mathrm{~cm}$ diameter spot). So, even with the lost of some virus through nitrocellulose membrane po rus, we can assay a quantity of serum 5 -fold hi gher than simple direct spotting, allowing grea ter sensitivity. Unlike other groups ${ }^{26,29}$, we did not, identify any serum inhibitor of DNA binding to nitrocellulose, as our sensitivity was increased when performing direct spotting. ZELDIS et al., $1986^{31}$ suggest that the 5 'binding protein could work as a bridge to the membrane. Perhaps in te ractions between viral envelope and core pro teins with the nitrocellulose, involving or not po lymerised serum albumin, enhance the retention of viral particles.

Other method proposed to $\mathrm{HBV}$ replication monitoring is the detection of serum viral DNA polymerase activity. LIN et al., $1984^{10}$ developed a simplified technique, slightly modified by us To our knowledge, Lin's method was never compared with HBV-DNA detection. This assay has shown a good correlation with hybridization (33/38-86.8\%) and HBeAg positivity (29/40 $72.5 \%$. We found 3 sera HBV-DNA positive and DNA polymerase negative, and 2 other with in verse parameters. The former were all HBeAg positive and the latter were one HBeAg positive and one anti HBe positive. This last serum was also anti-delta positive, and, it might represent a false positive for DNA polymerase. Another possibility is that the virus delta interferes with the results of this assay. Studies involving more anti-delta positive cases will be performed to en large our knowledge about this.

In conclusion, assaying viral DNA polyme rase using the technique developed by LIN et al. is a good marker for $\mathrm{HBV}$ replication, al though false positive samples could rarely ap 
PINHO, J. R. R. FONSECA. L. E. P. da: SONG. Yu: MIYAMOTO. Y.: CARRILHO. F. J.: GRANATO. C. F. H. \& SILVA. L. C da - Comparison of serum hepatitis B virus replication markers in patients with chronic hepatitis B: studies on HBeAg Anti HBe system, viral DNA polymerase and HBV-DNA. Rev. Inst. Med. trop. S. Paulo. $31(5): 328335,1989$

pear. Comparing to hybridization, it has the ad vantage of involving tritium labelled nucleoti des, that are less hazardous, easier to handle, and have longer half-life. Careful storage of sera is very important because the enzyme is very labile ${ }^{13}$. We are now trying to simplify the precipitation and washing steps, optimize positive ne gative ratio and reprodutibility, which is a com mon problem involving enzymatic reactions.

For the first time in our country, the comparison between HBeAg anti-HBe system and mo lecular biological replication markers in chronic hepatitis B patients was performed. This is very important due to high geographic variability of this correlation. Our results show that among HBeAg positive anti-HBe negative patients, $19.2 \%$ do not show other serum replication mar ker and $80.8 \%$ show one of them at least. On the other hand. 19 anti-HBe positive patient had detectable DNA polymerase but no HBV-DNA. This sample was already discussed above. None of our anti-HBe positive sample shown $\mathrm{HBV}$ DNA.

These results are intermediate to those from other groups, where $\mathrm{HBV}$ replication markers were found in most $(67-100 \%) \mathrm{HBeAg}$ positive samples and in few to more than half anti-HBe positive samples. Many reasons may explain our results. First. we studied chronic hepatitis $B$ patients, some of them evolving by spontaneous or induced HBeAg anti-HBe seroconversion. that could explain the HBeAg positive DNA negative sera. Second, some patients in advanced stages of disease could maintain this serological pattern ${ }^{6 .}{ }^{17}$. Third, São Paulo is a region were the HBV prevalence is about $2 \%^{5}$, corresponding to medium endemicity region, with a paucity of studies through the world at this point. This could explain the intermediate characteristic of our population, with more HBeAg DNA negative patients than Northern Europe and USA, and with fewer anti. HBe DNA positive patients than found in highly endemic areas. Studies with larger populations, from different ethnic and re gional origins will be performed in a larger study.

Anyway, these data clearly demonstrate so me disagreement between $\mathrm{HBeAg}$ and $\mathrm{HBV}$ DNA or DNA polymerase detection in chronic hepatitis $B$ patients and reinforce the necessity of monitoring them in the follow up of these pa tients. Comparison between sorologic markers and detection of tissual viral antigens and in situ hybridization are under investigation in our laboratories.

\section{RESUMO}

Comparaçāo dos marcadores sorológicos da replicação do vírus da hepatite $B$ : estudos sobre o sistema AgHBe/anti-HBe, DNA polimerase viral e HBV-DNA.

A detecção do genoma do HBV no soro por hibridização molecular é o mais sensivel e espe cífico marcador da replicação e infectividade do HBV. sendo sua utilização proposta como técni ca rotineira no acompanhamento de doenças re lacionadas a este vírus. Comparando diferentes técnicas descritas anteriormente, escolhemos a deposição direta das amostras séricas sobre a membrana de nitrocelulose sob filtração a vá cuo, seguida de banhos desnaturan tes e neutrali santes como mais prática e simples, com sensibi lidade equivalente.

O ensaio da DNA polimerase usando ácido fosfonofórmico como inibidor viral específico mostrou $86.8 \%$ de concordáncia com a detecção direta do DNA viral, sendo, portanto, uma alter nativa viável no acompanhamento de pacientes com hepatite crônica $B$

Encontramos 19,2\% das amostras AgHBe positivos sem outros marcadores de replicaçāo viral. Por outro lado, nenhuma amostra anti HBe positiva teve HBV-DNA detectável. Discor dância entre estes dois sistemas foi extensamen te descrita, e confirmamos pela primeira vez este fato em pacientes com hepatite crônica $B$ em nosso país. Técnicas de biologia molecular são. portanto. fundamentais na determinaçảo da replicação viral em cada paciente.

\section{ACKNOWLEDGEMENTS}

We are grateful to Doctors José Carlos da Costa Maia and Maria Helena Juliani for the al. pha -32 P - dATP, and to Doctors Francis Galibert and Christian 'Trépo for the plasmid contai. ning the cloned HBV genome, to whom we are deeply indebted. 
PINHO. J. R. R.: FONSECA, L. E. P. da: SONG. YU: MIYAMOTO. Y: CARRIIHO. F. J.: GRANATO. C. F. H. \& SILVA. L. C. da - Comparison of serum hepatitis B virus repication markers in patients with chronic hepatitis B: studies on HBeAg Anti HBe system, viral DNA polymerase and HBV-DNA Rev. Inst. Med. trop. S. Paulo, $31(5): 328335,1989$

\section{ABREVIATIONS}

HBV - Hepatitis B Virus

$1 \times \mathrm{SSC}-0.15 \mathrm{M} \mathrm{NaCl}, 0.015 \mathrm{M}$ Sodium $\mathrm{Ci}$ trate

$1 \times$ Denhardt $-0.02 \%$ Ficoll, $0.02 \%$ Polivynilpirrolidine, $0.02 \%$ BSA

BSA -. Bovine sorine albumin.

\section{REFERENCES}

1. BERNINGER. M: HAMMER, M.: HOYER, B. \& GERIN, J. L. - An assay for detection of the DNA genome of hepa titis B virus in serum. I. med. Virol., 9: 5766.1982.

2. BONINO, F: HOYER, B \& NELSON, J. - Hepatitis B virus DNA in the sera of HBs antigen earriers: a marker of active bepatitis $B$ virus replication in the liver. Hepato$\log \mathbf{y}, 1: 386-391,1981$.

3. BRECHOT, C.; HADCHOUEL, M.; SCOTTO, J.: DEGOS, F.: CHARNAY, P.: TREPO, C. \& TIOLLAIS, P. - Detec tion of hepatitis $B$ virus DNA in liver and serum: a direct appraisal of the chronic carrier status. Lancet, 2: 756768. 1981.

4. BRECHOT, C.: DEGOS, F.: LUGASSY, C.: THIERS. V. ZAFRANI. S.: FRANCO, D : BENHAMOU, J. P.: WANDS, J.: ISSELBACHER, K.; TIOLLAIS, P. \& BERTHELOT. P. - Hepatitis B virus DNA in patients with chronic liver discase and negative tests for hepatitis B surface antigen. New Engl. J. Med.. 312: 270 276, 1985.

5. CARRILHO. F. J. \& DA SILVA. L. C. - Epidemiologia. In: DA SILVA. L. C.. ed. Hepatites agudas e cronicas. Sāo Paulo, Sarvier, 1986. p. 47-69.

6. CHAUSSADE, S.: THIERS, V.: BOBOC. B.; HOUSSET. C.; BRECHOT. C. \& DEGOS. F. - Lantigene HBe et l'ADN du virus $B$ chez les malades d hepatite chronique active. Gastroenterol. clin. biol., 10: 744 747, 1986.

7. CHU, C. M: KARAYIANNIS, P.; FOWLER, M. J. F : MON JARDINO. J.; LIAW, Y.F. \& THOMAS, H. C. -- Natural history of chronic hepatitis $B$ virus infection in Taiwan: studies of hepatitis B virus DNA in serum. Hepalology, 5: 431434,1985

8. CRAXI, A.; WELLER, I. V. D. \& BASSENDINE, M. F - Relationship between HBV specific DNA polymerase and HBe antigen antibody system in chronic $\mathrm{HBV}$ infec tion: factors determining selection of patients and outco me of antiviral therapy Gut, 24: 143 147.1983

9. FEINMAN, S. V : BERRIS, B.; GUHA, A : SOOKNANAN, R. BRADDLEY. D. W : BOND. W. W. \& MAYNARD, J. E. DNA: DNA hybridization method for the diagnosis of hepatitis B infection. J. virol. Meth., 8: 199 206, 1984

10. FIGUS, A.; BLUM, H. E.: VYAS, G. N.; DE VIRGILIS, S.: CAO, A.: LIPPI. M.: LAI, E. \& BALESTRIERI. A. -
Hepatitis $B$ viral sequences in non $A$, non $B$ or hepatitis B virus related chronic liver disease. Ilepatology, 4: 364368,1984

11. GENESCA. J.; JARDI. R.: PRAT S.: BUTI. M.: STEBAN R : HERNANDEZ, J M.: LOPEZ VIVANCOS. J.: PUIG DOMENICH, P \& GUARDIA. J. - Valor de la determi nación serica del DNA del virus de la hepatitis $\mathrm{B}$ como marcador de replicación virica. Med. clin. (Barcelona), 87: 665668.1986

12. GERBER, M. A. \& THUNG, S. N. - Biology of disease: molecular and cellular pathology of hepatitis. Lab. Invest., 52: 572590.1985

13. GRANATO, C. F. H. - Avaliaçāo do grau de replicaçào viral em individuos aguda ou cronicamente infectados pelo virus da hepatite $B$ : estudo sobre o antigeno HBe. Sào Paulo. 1988. Dissertaçáo de mestrado - Faculdade de Medicina da Universidade de Sáo Paulos

14. GUST. I. D . BURRELL, C. J.: COULEPIS. A. G.: ROBIN SON. W. S. \& ZUCKERMAN. A. J. - Taxonomic classifi. cation of human hepatitis B virus. Intervirology, 25: 14.29 . 1986 .

15. HARRISON, T. J.: BAL, V.: WHEELER, E. G.: MEA COCK. J. J.: HARRISON, J. F. \& ZUCKERMAN. A. J. - Hepatitis B virus DNA and e antigen in serum from blood donors in the United Kingdom positive for hepatitis B surface antigen. Brit. med. J., 290: 663 664. 1985.

16. KAPLAN P. M.: GREENMAN, R. L.: GERIN, J. L.: PUR CELL, R. H. \& ROBINSON, W. S. - DNA polymerase associated with human hepatitis B antigen. J. Virol., 12: 995-1005, 1973.

17. KARAYIANNIS, P.; FOWLER, M. J. F : LOK, A. S. F : GREENFIELD, C.: MONJARDINO, J. \& THOMAS, H. C. - Detection of serum HBV DNA by molecular hybridi zation: correlation with $\mathrm{HB}$ Ag anti $\mathrm{HB}$ e status, racial origin, liver histology and hepatocellular carcinoma. $\mathbf{J}$. Hepat., 1: 99 106. 1985.

18. LIEBERMANN. H. M. LEBRECQUE. D. P.; KEW M. C. HADZIYANNIS. S. J. \& SHAFRITZ, D. A. - Hepatologic detection of hepatitis $B$ virus DNA cirectly in human serum by a simplified molecular hybridization test: comparison to HBeAg ant HBestatus in HBsAg carriers. II patolone, 3: $285-291,1983$

19. LIN, H. J.: WU, P.: LAI, C. L.: \& CHAK, W. - Mirromethod for phosphonoformic inhibition assay of hepatitis $B$ viral DNA polymerase. Clin. Chem., 30: 549 552. 1984

20. MANIATIS, T : FRITSCH, E. F. \& SAMBROOK J.-.Iolecular cloninæ: a laboratory manual. Cold Sprine Ifar bor. NY, Cold Spring Harbor Laboratory, 1982.

21. MEINKOTH. J. \& WAHL, G. -- Review: hybridization of nucleic acids immobilized on solid supports. Analyt. Biochem., 138: 267-284, 1984 .

22. MORACE, G.: VON DER HELM, K, \& DEINHARDT. F. - Detection of hepatitis B virus DNA in serum by a rapid filtration hybridization assay. J. virol. Meth., 12: 235242 . 1985 
PINHO, J. R. R.; FONSECA. L. E. P. da: SONG. Yu: MIYAMOTO. Y.: CARRILHO, F. J.; GRANATO. C. F. H. \& SILVA, L. C. da - Comparison of serum hepatitis B virus replication markers in patients with chronic hepatitis B: studies on HBeAg Anti HBe system, viral DNA polymerase and HBV-DNA. Rev. Inst. Med. trop. S. Paulo. 31(5): $328-335,1989$.

23. NORDENFELT, E. I. \& KJELLEN, L. - Dane particles. DNA polymerase, and e antigen in two distinct categories of hepatitis B antigen carriers. Intervirology, 5: 225232 . 1975.

24. RIGBY, P. W. J.: DIECKMAN, M.; RHODES, C. \& BERG. P. - Labelling deoxyribonucleic acid to high specific acti vity in vitro by nick translation with DNA polymerase I. J. molec. Biol., 113: 237 25i. 1976.

25. RINTJES. P. J. M.: VAN DITZHUIJSEN, J.; VAN LOON. A. M. VAN HAELST. V. J. G. M.: BRONKHORST. F. B. \& YAP, S. H. - Hepatitis B virus DNA detected in formalin fixed liver specimens and its relation to serologic markers and histopathologic features in chronic liver di sease. A mer. J. Path., 120: $411418,1985$.

SCOTTO, J.; HADCHOUEL, M.; HERY, C.; YVART, J.: TIOLLAIS, P. \& BRECHOT, C. - Detection of hepatitis $B$ virus DNA in serum by a simple spot hybridization tech. nique: comparison with results for other viral markers. Hepatology, 3: 279.284, 1984

27. STANDRING. D. N. \& RUTTER, W. J. - The molecular analysis of hepatitis $B$ virus. In: POPPER. H. \& SCHAFF
NER, F.. ed. - Progress in tiver diseases. Orlando. Grunt: \& Stratton, 1986. v. 8, p. 311331.

28. VAN DITZHUIJSEN, T. J. M.: SELTEN, G. C. M.: VAN LOON, A M.: WOLTERS, G.: MATTHYSSEN. L. \& YAP S. H. - Detection of Hepatitis B virus DNA in serum and relation with IgM class anti $\mathrm{HB}$ c titers in hepatitis B virus infection. J. med. Virol., 15: 49.56. 1985.

29. WALTER, E.: BLUM, H. E.: OFFENSPERGER, W, B. ZESCHNIGK. C.: OFFENSPERGER. S. \& GEROK. W - Spot-blot hybridization assay for the detection of hepa titis $B$ virus DNA in serum: factors determining its sensi tivity and specificity. Hepatology, 7: 557562,1987

30. WELLER, I. V. D.; FOWLER. M. J. F.: MONJARDINO J. \& THOMAS, H. C. - The detection of HBV DNA in serum by molecular hybridization: a more sensitive me thod for the detection of complete HBV particles. J. med. Virol., 9: 273 280. 1982.

31. ZELDIS. J. B.: BEN PORATH. E.: ENAT, R.: KIRSCH K. \& WANDS. J.-- Correlation of HBV DNA and mono clonal reactivity to $\mathrm{HBSAg}$ in serum of patients with $\mathrm{HBV}$ infection. J. virol. Meth., 14: 153 166, 1986

Recebido para publicaçào em 1361989 